\title{
Exploiting opportunities at all cost? Entrepreneurial intent and externalities
}

\author{
Diemo Urbigabc \\ Utz Weitzelab \\ Stephanie Rosenkranz ${ }^{\mathrm{d}}$ \\ Arjen van Witteloostuijn ${ }^{\text {cde }}$ \\ ${ }^{a}$ Radboud University of Nijmegen, Department of Economics \\ bMax Planck Institute of Economics, Germany \\ 'University of Antwerp, Faculty of Applied Economics \\ dUtrecht University, Utrecht School of Economics \\ eTilburg University, Faculty of Economics and Business Administration
}

March 2011

\begin{abstract}
:
Do potential entrepreneurs exploit welfare-destroying opportunities as much as they exploit welfare-enhancing opportunities as it is assumed in several normative models? Do we need to prevent potential entrepreneurs from being destructive or are there intrinsic limits to harm others? We experimentally investigate how people with different entrepreneurial intent exploit risky investment opportunities that are associated with negative and positive externalities. We find that participants who consider entrepreneurship as a future occupation invest significantly less than others in destructive opportunities. Nevertheless, our results support prior evidence that the entrepreneurially talented invest more in destructive opportunities. The latter effect seems to be entrepreneurship-specific, because the investment behavior of the generally more talented does not differ from that of other participants. Taken together, our results suggest that people who are willing to exploit destructive opportunities do not only do this in private ventures, but also - and maybe even more so - in wage employment.

Highlights:

* We examine correlations between entrepreneurial attitudes, investment with externalities and other-regarding behavior.

* We consider investments causing positive, negative, and no externalities.

* Entrepreneurial self-efficacy correlates with more investment in general.

* Entrepreneurial intent correlates with less investment for negative externalities.
\end{abstract}

Keywords \& JEL classification:

3000 - Social Psychology (PsycINFO); L26 - Entrepreneurship (JEL); D62 Externalities (JEL); C91 - Laboratory, Individual Behavior (JEL)

\section{Acknowledgements}

The authors thank Katrin Burmeister-Lamp, Werner Güth, Christian Schade, Erik Stam, three anonymous reviewers and the involved editors, the participants of the IPGC workshop (ImperialCollegeinLondon, May 2009), the Annual Max Planck Ringberg Conference on Entrepreneurship (Tegernsee, June 2009), and the DIW Berlin/IZA Workshop on Entrepreneurship Research (Bonn, February, 2010) for valuable ideas and comments. All remaining errors are ours. Diemo Urbig gratefully acknowledges the financial support through the Odysseus program of the Flemish Science Foundation (FWO). 


\section{Introduction}

Entrepreneurship is often considered as a productive force, as is evident in Schumpeter (1911), who puts the entrepreneur center stage in his theory of innovation and capitalist development. Baumol (1990) and Murphy et al. (1991) argued, however, that entrepreneurial talent maximizes private returns that do not need to be aligned with social returns and, therefore, may allocate into unproductive activities, such as rent-seeking. The latter is commonly understood as "any redistributive activity that takes up resources" (Murphy et al., 1993: 409). Based on such allocation models, these researchers call for institutions that better guide, or limit, entrepreneurial activities. The assumption of self-interested entrepreneurs is present in other entrepreneurship models, too. For instance, based on the assumption of private return maximization, models of financial contracting between entrepreneurs and venture capitalists predict efficiency losses due to resulting moral hazard dilemmas (Casmatta 2003; Eltizur \& Gavious, 2003; Fairchild, in press). These inefficiencies would be reduced by the existence of entrepreneurs with less selfish attitudes (Fairchild, 2010). Entrepreneurs' attitudes toward selfishness and benevolence are, therefore, of wide interest, inside and outside more narrow fields such as social responsibility and social entrepreneurship (see, e.g., Dees, 2007; Tracey \& Jarvis, 2007).

The theoretical assumption of private return maximization, which is causal for the previously mentioned inefficiencies and welfare losses, was challenged by empirical and experimental economists, who find across many contexts that people care about others (e.g., Fehr \& Schmidt, 1999; Bolton \& Ockenfels, 2000; Andreoni \& Miller, 2002). While there is an ongoing discussion on the reasons for these findings (see Binmore \& Shaked, 2010; Fehr \& Schmidt, 2010; Wilson, 2010), the observed pattern is unambiguous: whether the reasons are fairness, inequity aversion, or altruism, on average, people do not seem to exclusively allocate their resources into activities with the highest private returns if they harm other people's returns.

Given this contrast between entrepreneurship models and experimental evidence, Weitzel et al. (2010) investigated the association of entrepreneurship with selfish behavior in dictator games. They study whether the general finding of caring 
about others equally holds for entrepreneurially talented people. While empirical entrepreneurship literature provides many insights into various personality traits, which includes openness, conscientiousness, extraversion, agreeableness and neuroticism (representing the "Big Five": John \& Srivastava, 1999; applied to entrepreneurship by, e.g., Zhao et al., 2010; Gruber, in press), there is a research gap with respect to fairness, honesty, and benevolence. Benevolence is a personality trait that in recent personality research emerged as a sixth important trait, next to the "Big Five" (Ashton \& Lee, 2007; Hilbig \& Zettler, 2009). Weitzel et al.'s (2010) findings show that believing to be better than others in doing business is negatively associated with benevolence. This especially holds true for people who report that they are less creative. Weitzel et al.'s (2010) results reinforce the stereotype of the socially interested creative person versus the less creative, but more selfish, businessman.

However, the question remains whether entrepreneurially talented people actually try to start a business or try to get venture capital for a start-up. It is therefore also questionable whether the selfishness of entrepreneurially talented people does actually translate into welfare losses due to negative externalities and moral hazard problems. In fact, entrepreneurship research suggests that many factors other than entrepreneurial talent, such as individual values, social norms and formal institutions, influence whether or not people actually start or attempt to start a business (Krueger et al., 2000, Kolvereid \& Issaksen, 2006, Krueger, 2009). Further, following Baumol's (1990) argumentation that institutions are needed to channel the allocation of entrepreneurial intent, Bowen and DeClerq (2008) as well as Sobel (2008) show that institutions are indeed effective in determining people's allocation into different types of entrepreneurship. Thus, formal and informal institutions have the potential to sort the group of a society's entrepreneurs, from very social to very egoistic, into specific types of entrepreneurial activities. It is, therefore, unclear whether those people who perceive being talented for starting a business behave in the same way as those who effectively want to start one up. While Weitzel et al's (2010) results reflect an interesting first study on entrepreneurially talented people, they do not, however, allow to conclude anything about people who actually intent to start a business and, perhaps, apply for venture capital. 
The contribution of this study is to test the relationship between entrepreneurial intent and benevolent preferences. In order to elicit the degree to which participants care about other participants' returns, this study does not use dictator games, but confronts participants with multiple risky investment opportunities and the decision on how much to invest in these opportunities. By investing, participants impose either positive, negative or no externalities on a separate group of participants; the more they gain the more will others loose or gain. We refer to these investment opportunities as productive, destructive and neutral, respectively. This design puts decisions on risky investments center stage, and allows a direct comparison of productive with destructive investment opportunities, as well as a comparison of both with opportunities not involving others. By combining measures of entrepreneurial intent, entrepreneurial self-efficacy and general selfefficacy with participants' investment behavior, we can analyze whether or not these personality characteristics are associated with the level of participants' exploitations of destructive and productive opportunities. Besides investigating the dependency between entrepreneurial intent and investment behavior, we can also test if this relation is different for entrepreneurial talent (self-efficacy). Moreover, by comparing perceptions of entrepreneurial talent with those of general talent, we can test if a potential talent effect as the one observed by Weitzel et al. (2010) is entrepreneurship-specific.

To the best of our knowledge, this is the first test of the association of entrepreneurial intent, on the one hand, and benevolent or selfish behavior, on the other hand. Our experimental results show that participants who consider entrepreneurship as a future occupation invest significantly less than other people in destructive opportunities (and as much as others in productive and in neutral ones). This is the opposite effect of people with entrepreneurial talent: consistent with Weitzel et al. (2010), we find that participants who perceive themselves as being good in doing business invest more in destructive opportunities (and more in neutral and in productive opportunities). Further, extending Weitzel et al. (2010) and in support of Baumol (1990), we show that indeed entrepreneurship-specific talent, and not general talent, plays a distinct role in investment decisions with negative externalities: the investment behavior of the generally talented does not differ from that of other 
participants, neither for productive nor for destructive opportunities. Taken together, our results imply that, in contrast to generally talented people, entrepreneurially talented people who are willing to exploit destructive opportunities do not confine such activities to private ventures, but may also pursue them - and possibly even more so - in other occupations.

The remainder of this paper is structured as follows. Section 2 discusses the theoretical background and related research. Section 3 describes the design, procedure and hypotheses of the experiment. Section 4 reports the results, which are discussed in the concluding Section 5.

\section{Related research}

This study is part of a larger research stream studying the personality-related correlates of entrepreneurship (Rauch \& Frese, 2007), which includes openness, conscientiousness, extraversion, agreeableness, and neuroticism (e.g., Zhao et al., 2010; Gruber, in press), optimism (Hmieleski \& Baron, 2009), locus of control (Bonnett \& Furnham, 1991, Wijbenga \& van Witteloostuijn, 2007), but also risk preferences (Brockhaus, 1980; Caliendo et al., 2009), need for control or need for autonomy (Brockhaus, 1982), and achievement motivation (Bonnett \& Furnham, 1991, Wijbenga \& van Witteloostuijn, 2007). This study contributes to this research by motivating the relevance of benevolence as a personality characteristic to be addressed in entrepreneurship research. In doing so, entrepreneurship research would follow recent psychological research on personality traits that argues that honesty and humility represent a sixth personality trait complementing the more established five-dimensional 'Big Five' personality models (Ashton \& Lee, 2007). This new factor relates to fairness and greed. Recently, this sixth trait has been empirically shown to be associated with benevolent behavior in dictator games (Hilbig \& Zettler, 2009). This study investigates the correlations between benevolence, on the one hand, and entrepreneurial intentions, as well as entrepreneurial and general self-efficacy, on the other hand.

Recent research on the relation of personality characteristics and entrepreneurship focuses on the role of personality in the formation of entrepreneurial intentions and resulting venture performances (Rauch \& Frese, 2007; 
Hmieleski \& Baron, 2009; Zhao et al., 2009). These studies provide a more detailed understanding of how people select occupations and how specific personality characteristics help or hinder the pursuit of entrepreneurial opportunities. Specific elements of one's personality can influence the motivation to start a business - e.g., the need for autonomy (Brockhaus 1982) or the need to avoid risks (Caliendo et al., 2009). Personality also affects a potential entrepreneur's perceived fit with tasks required to start a business and this fit finally also impacts the performance in entrepreneurial occupations (Zhao et al. 2009; Caliendo et al., 2010). While rarely discussed, fairness and benevolence play an important role in many business processes that potentially involve moral hazard. With respect to entrepreneurship, such issues may be raised within an entrepreneurial team, but also in relation to other business partners (Fairchild, in press). Fairchild (2010), for instance, shows how selfishness of entrepreneurs, via moral hazard risks, causes inefficiencies in relations with venture capitalists. As such, the allocation of personalities with respect to selfishness and benevolence across different roles and players in an economy can substantially affect the efficiency, the success, and the failure of entrepreneurship.

Our motivation to consider entrepreneurs' personalities does not solely refer to their role in the formation of intent or in increasing returns for the entrepreneur and other shareholders. Instead, we also look at the entrepreneur's personality in order to identify the potential threat resulting from successful entrepreneurship that can cause substantial negative externalities to other parts of a society. As Baumol (1990) points out, high individual returns to highly talented entrepreneurs do not exclude negative externalities to society. To illustrate such unproductive entrepreneurship in excessive litigation and legal engagement, Baumol (1990) refers to "a previously unused legal gambit that is effective in diverting rents to those who are first in exploiting it" (p. 897). He also regards novel ways of tax evasion and avoidance as an important form of unproductive entrepreneurship. Other areas of entrepreneurial rent-seeking that Baumol (1990: 915) cites are "speculative financial transactions without much (if any) contribution to the productive capacity of the economy." Assuming that entrepreneurially talented people exploit opportunities that maximize their private return irrespective of potentially associated externalities, Baumol (1990) calls for formal institutions to channel entrepreneurial energy into more productive activities 
rather than unproductive activities and rent-seeking. If Baumol's (1990) assumption exaggerates actual entrepreneurs' selfishness, formal institutions preventing destructive behavior may lead to overregulation, which may crowd out intrinsic motivation for benevolent behavior (e.g., Frey, 1997; Frey \& Oberholzer-Gee, 1997).

To sum up, entrepreneurs' personalities and their values with respect to selfishness and benevolence have a substantial economic impact: micro-economically with respect to principal agent and cooperation dilemmas related to new venture formation; macro-economically with respect to the type of entrepreneurial opportunities that is selected for further development (i.e., productive, neutral or destructive). It is therefore important to understand the social preferences of business people in general, and of entrepreneurs in particular.

While people are generally found to not only maximize their private returns (Fehr \& Schmidt, 1999; Bolton \& Ockenfels, 2000; Andreoni \& Miller, 2002; Binmore \& Shaked, 2010; Fehr \& Schmidt, 2010; Wilson, 2010), it is an open question whether or not this personality dimension equally applies to entrepreneurs. Entrepreneurs have been found to differ from managers and other people along various personality dimensions, e.g., with regard to their need for control or their need for autonomy (Brockhaus, 1982) and their achievement motivation (Bonnett \& Furnham, 1991; Wijbenga \& van Witteloostuijn, 2007). We are, however, not aware of any empirical research that sheds light on their specific social preferences.

Theoretically, there are multiple mechanisms that may lead to a heterogeneous allocation of selfishness across different economic roles. In motivating personality differences of entrepreneurs, Zhao et al. (2010) suggest that people seek occupations that match their personality. Within the context of organizational behavior, Schneider (1987: 441) discusses mechanisms leading to specific allocations of persons to organizations: "Attraction to an organization, selection by it, and attrition from it yield particular kinds of persons in an organization. These people determine organizational behavior." Such arguments can be used to motivate a positive but also a negative association between benevolence and entrepreneurship. If entrepreneurship is associated with, and if entrepreneurs' role images corroborate, private profit maximization, then it is very likely that such people also allocate into entrepreneurship (see Starr \& Fondas, 1992, on entrepreneurs' roles and 
socialization). The opposite can, however, be argued, too. Fehr and Schmidt (2000) and Lazear and Shaw (2007) argue that people chose their jobs according to the offered compensation scheme and that the perceived fairness of these schemes influences their choice. Among the important elements contributing to the perceptions of the compensation schemes is a direct relation between one's own performance and the resulting rewards (Lazear \& Shaw, 2007). Believing in a high influence of own performance on final outcomes reflects an internal locus of control (Rotter, 1975), which is usually assumed to be stronger for entrepreneurship than for other occupations (Locke \& Baum, 2007). Moreover, a direct relation between individual performance and compensation maybe considered as fair, because the decisions of others and of potential free-riding behavior play a smaller role. If this is the case, then people who value a fair compensation for their efforts may have a higher tendency to allocate into entrepreneurship. These are two of possibly various mechanisms that generate heterogeneity across entrepreneurship and other occupations with respect to benevolent behavior. We can, therefore, not assume that the subpopulation of entrepreneurs mirrors people's average fairness and benevolence preferences.

The study by Weitzel et al. (2010) makes a first step in studying the association of entrepreneurship and benevolent behavior. In a laboratory experiment, Weitzel et al. (2010) elicit participants' other regarding behavior based on several different versions of the dictator game. Weitzel et al.'s (2010) experimental results show that independent of the version of the dictator game, entrepreneurial talent was generally negatively associated with benevolent behavior. This relation was, however, moderated by the participants' self-reported belief to be creative. With respect to the business component of entrepreneurial talent, Weitzel et al.'s (2010) results seem to support Baumol's (1990) assumption that entrepreneurial talent seeks to maximize private but not social returns, or at least does this more than other people. These first results on the association between entrepreneurial talent and benevolence, however, are silent about people who actually intent to start a business and to what degree these potential entrepreneurs care about the associated externalities.

Believing in high entrepreneurial talent does not automatically imply the intent to start a business. According to Bird (1988), entrepreneurial intent is the first critical step in the process of becoming an entrepreneur. In the formation of entrepreneurial 
intentions, research has highlighted the important role of entrepreneurial self-efficacy or the belief to be able to perform activities required to start a business (Krueger et al., 2000). Based on the theory of planned behavior (Ajzen, 1991), however, a number of studies argue and show empirically that social norms can lead people who expect to be successful entrepreneurs to nevertheless choose a different occupation (Kolvereid \& Isaksen, 2006; Ikovleva \& Kolvereid, 2009). Exploiting the moderating role of social norms and institutions, Baumol (1990) calls upon politicians to implement institutions that prevent entrepreneurially talented people from selecting into potentially destructive activities. Baumol's (1990) policy recommendations thus explicitly hinge on the distinction between talent and intent. Empirical studies by Bowen and De Clercq (2008) and Sobel (2008) reveal that institutions and social norms do, indeed, influence people's occupational choices into entrepreneurship in general, and into productive versus destructive entrepreneurship in particular. It is therefore unlikely that the group of people who start or intent to start a business have a similar personality profile as the group of people with entrepreneurial talent.

Based on the theoretically predicted and empirically observed differences between talent and (planned) actions, our study contributes to the understanding of benevolence and entrepreneurship by considering entrepreneurial intentions. The latter are operationalized as people's perceived likelihood of starting an own business during the next five years (Krueger et al., 2000). These intentions already incorporate people's perceptions of social norms and institutions that encourage or hinder entrepreneurship (Krueger et al., 2000; Kolvereid \& Isaksen, 2006). They also capture people's preferences that are independent of their talent. The intention - as it is measured here - reflects the entrepreneurial occupational choice short of the final act of actually starting a business to exploit an entrepreneurial opportunity. We therefore study potential entrepreneurs that are still searching for, identifying or developing opportunities, and analyze how much they care about negative (and positive) externalities. By additionally eliciting people's entrepreneurial self-efficacy, we are able to compare the associations of participants' other-regarding behavior with both entrepreneurial intent and self-efficacy.

While the relation between benevolence and entrepreneurial intent is the main focus of this study, we would also like to draw attention to a related, though different 
aspect. A number of talent allocation models (Murphy et al., 1993; Acemoglu, 1995) followed Baumol's (1990) pioneering work on the allocation of entrepreneurial talent. However, these models do not assume entrepreneurial talent as a necessary condition for rent-seeking activities. Instead, they focus on more general talent, consisting of, for instance, "great intelligence, energy, or other generally valuable traits. Such people [...] can become entrepreneurs, government officials, lawyers, speculators, clerics, etc." (Murphy et al., 1991: 504). In these models, general talent of the "best and the brightest" (Murphy et al., 1991: 505), not entrepreneurial talent, is deemed sufficient to be a productive entrepreneur. ${ }^{4}$ This poses an interesting question to Baumol's (1990) model and predictions as well as to Weitzel et al.'s (2010) empirical findings: if entrepreneurial talent is not identical to general talent, which of the two, if at all, is then to blame for rent-seeking and other unproductive entrepreneurial activities? By eliciting participants' entrepreneurial self-efficacy and their general self-efficacy, we are able to shed light on whether or not entrepreneurial talent has a distinct association with benevolent behavior.

\section{The experiment and the study design}

\subsection{Study design}

We examine the association between entrepreneurship and benevolent behavior at the micro level by means of a correlation study that uses an incentivized laboratory experiment to elicit benevolent behavior ${ }^{5}$ and psychometric scales to measure entrepreneurial intent, which are "indications of how hard people are willing to try [...] to perform the behavior" (Ajzen, 1991: 181), entrepreneurial self-efficacy, defined as one's self-attributed ability to perform activities required to start a business (Krueger et al., 2000), and general self-efficacy, defined as the self-perception of one's ability to perform well across a variety of different situations (Judge et al., 1997). The study design combines experimentally elicited as well as self-reported personality

\footnotetext{
${ }^{4}$ In their allocation model of general talent, Murphy et al. (1991: 503-504) explicitly stress that "[s]ome people have strong comparative advantage from natural talent for particular activities, such as singing, painting, or playing basketball. [...] But other people do not have such great specialized abilities, but at the same time possess great intelligence, energy, or other generally valuable traits. Such people can become one of the best in many occupations, unlike the best singer or basketball player. They can become entrepreneurs, government officials, lawyers, speculators, clerics, etc."

${ }^{5}$ For a discussion on the use of experiments in entrepreneurship research, see Schade (2005), and Schade and Burmeister (2009).
} 
characteristics, and is similar to the design employed by Elston and Audretsch (forthcoming) and by Weitzel et al. (2010).

We confront participants with an entrepreneurial investment decision with risky payoffs and positive, negative, as well as neutral externalities. The basic investment decision is based on one of the earliest notions of entrepreneurial behavior by Richard Cantillon (1730), who identified the willingness to bear the personal financial risk of a venture as the defining characteristic of an entrepreneur. In our experiment, participants receive a fixed budget $B^{A}$ and can then either invest an amount $\left(I \leq B^{A}\right)$ into a coin toss $c$, with $c \in\{0,1\}$, or do not invest at all $(I=0)$ and simply keep the budget $B^{A}$ as a safe income. If participants decide to invest into the coin toss, they receive a multiple of the invested amount, $m-I$ (with $m>\mathbf{1}$ ), as a return $R$ to their investment if they win, and nothing if they lose:

$$
R=\left\{\begin{array}{c}
m-I \text { if } c=\mathbf{1} \\
0 \text { if } c=\mathbf{0}
\end{array}\right.
$$

Hence, their expected payoff from the risky investment decision is

$$
E\left[P^{A}\right]=B^{A}-I+p \cdot m \cdot I
$$

with a probability $p=0.5$ and $m>1$. Risk-loving participants would invest into the coin toss if $1<m<2$, as the expected return is lower than the invested amount $(p \cdot m \cdot I<I)$. With a multiple $m=2$, investments are risk neutral $(p \cdot m \cdot I=I) ;$ and with a multiple $m>2$, even risk-averse participants would choose to invest into the coin toss as their expected returns are higher than their investment $(p \cdot m \cdot I>I)$. We used the following four multiples in the experiment: $m=1.75, m=2, m=\mathbf{4}$ and $m=6$.

In order to apply the entrepreneurial investment decision explained above to the specific test of benevolent behavior, a treatment variable that introduces positive and negative externalities is needed. Only by adding such externalities, we can distinguish destructive from productive entrepreneurial investment. We therefore introduce two groups of participants, henceforth referred to as investors (Group A) and non-investors (Group B). The payoffs of investors are determined by their investment decisions as described above. The payoffs of non-investors, however, are solely and passively determined by investors' decisions, a condition that makes 
investments of investors subject to positive or negative externalities on non-investors - and hence to the impact of destructive (negative externalities) and productive (positive externalities) entrepreneurial behavior. The investors are informed of the nature and extent of the externalities ex ante.

Participants know from the start which group they belong to. In order to increase the number of observations for Group A (investors), $n^{I}$, we limit the size of Group B (non-investors) to $n^{N}=4<n^{I}$ participants. Participants in Group B equally share the average positive or negative externality of the participants in Group A. While this design cannot identify benevolent behavior in a one-to-one situation, the context of a group of people being exposed to externalities that are jointly caused by another group of investors mimics a possibly more realistic setting. The salience of fairness and benevolence considerations exert a substantial influence on corresponding behavior in laboratory experiments (Houser \& Xiao, 2010). According to Oechssler (2009), this limits the insights that can be gained from studying one-to-one dictator games, which were employed by Weitzel et al. (2010). Indeed, it is unlikely that benevolence considerations are the most salient feature in entrepreneurial decisions. In our setting, the positive or negative externalities of a single investor do not directly affect a single non-investor, but are conjointly, with the externalities caused by other investors, imposed on the group of non-investors. This makes the responsibility of a single investor not only less salient, but arguably more realistic. Results by Güth et al. (2008) and Brennan et al. (2008) suggest that risk considerations can lead to a crowding out of other-regarding behavior. Differences with respect to benevolent behavior in our setting may thus generalize easier to more realistic scenarios than results from dictator games, where fairness considerations are at the core of the game and extremely salient.

In order to avoid bankruptcy, all participants in Group B receive an initial budget $B^{N}$. Initial budgets are known to all players. The total payoff of a participant in Group B, $P^{N}$, is shown below. Essentially, it is a function of the average return $R_{i}$ of $n^{I}$ investors (indicated by $i$ ) distributed to $n^{N}$ non-investors and an 'impact factor' $\alpha$, which represents the treatment variable that determines the sign and intensity of the externality on non-investors: 


$$
P^{N}=B^{N}+\alpha \cdot \frac{1}{n^{I} n^{N}} \cdot \sum_{i=1}^{n^{I}} R_{i}
$$

In the experiment, the impact factor $\alpha$ could take nine different values from $\alpha=-1$ to $\alpha=+1$ in steps of $0.25:-1.0,-0.75,-0.5,-0.25,0.0,+0.25,+0.5,+0.75$, and +1.0- Investors' success exerts negative externalities on non-investors if $\alpha$ is less than zero and positive externalities if $\alpha$ is greater than zero. If it equals zero, then no externalities exist. Pooling of the externalities created by all investors in group A and sharing them among all receivers in group B generates a dependency at the session level, which needs to be taken into account when analyzing the data. In total, the four investment multiples $m$ and the nine impact factors $\alpha$ define 36 entrepreneurial investment decisions with differing returns to investments and differing externalities. In the following, we will refer to the different combinations of investment multiples and impact factors as 'scenarios'.

\subsection{Participants}

Based on the theoretical literature, people with entrepreneurial intent or entrepreneurial talent, present in any population, will self-select into the diverse set of activities available to them in their society. We therefore conducted our experiments with a diverse group of students for whom it is a priori unclear what activities the existing entrepreneurial talent among them will select into and who have not yet selected themselves. Despite the potential benefits of focusing on groups of professionals for experiments (Drehman et al., 2005; Alevy et al., 2007; Elston \& Audretsch, forthcoming), professional subjects have already made their occupational choice. In order to avoid any potential biases of occupational choice, we therefore focused on subjects who have not yet selected into, for instance, formally registered entrepreneurship or wage employment. For a more detailed discussion on the use of student samples in business research, we refer to Bello et al. (2009) and, in our specific context, Weitzel et al. (2010).

All participants in the experiment were drawn from a subject pool with approximately 1,400 students who were enrolled in bachelor and master programs at Utrecht University (The Netherlands). We recruited students from all disciplines, 
ranging from the natural to humanities and the social sciences. Altogether, 111 subjects participated, of which 87 were in group A of investors and 24 were in group B as non-investors. In group A, we have 32 male and 55 female participants with an average age of 21.7 (and a standard deviation of 3.14).

\subsection{Psychometric measurements}

To measure entrepreneurial intent we ask participants for their perceptions of the likelihood to become an entrepreneur within the next five years (Krueger et al., 2000). This self-predictive measure of entrepreneurial intent has been found to be consistent with other measures of entrepreneurial intent (Kolvereid \& Isaksen, 2006). Note that this measure reflects the preparedness for and expectations about the unexpected occurrence of an entrepreneurial opportunity (Kirzner, 1997; Shane \& Venkataraman, 2000; Shane, 2003). As discussed in the previous sections, entrepreneurial intent incorporates more factors than entrepreneurial self-efficacy. Those who believe that they will not start a business may do so because of a number of reasons. On the one hand, these reasons may be talent-related. They may believe that they are not able to identify an opportunity, to capture one that may occur unexpectedly, or to perform at a level that makes this opportunity more attractive than the currently available alternatives to entrepreneurship. On the other hand, they may also simply think that factors outside of their control, such as institutions, make them less likely to start a business. Our measure of entrepreneurial intent therefore captures more than talent. In fact, informal institutions such as social norms are shown to play an important role in the formation of entrepreneurial intent (Krueger et al., 2000; Kolvereid \& Isaksen, 2006, Ikoleva \& Kolvereid, 2009).

To classify people into more or less entrepreneurially talented participants, we measured entrepreneurial self-efficacy (ESE). Table 1 provides a list of all items. Chen et al. (1998) and Zhao et al. (2005) measure ESE by referring to very specific tasks and skills that are needed to start up and run a business. While Zhao et al.'s (2005) scale is less specific than the one by Chen et al. (1998), Wilson et al. (2007) offer an even better alternative. They measure ESE with no direct reference to start-ups and business operations. We therefore use this six-item scale in our study to measure entrepreneurial self-efficacy (ESE). For the items on entrepreneurial self-efficacy 
(ESE), suggested by Wilson et al. (2007), a common factor analysis shows onedimensionality, generating a single factor with an eigenvalue above one. ${ }^{6}$ The internal reliability is rather low with a Cronbach's alpha of 0.58. Upon closer inspection, we find that the scale includes one item with an extremely low factor loading of 0.09. After excluding this item, Cronbach's alpha increases to 0.66, indicating an internal reliability sufficient for further exploratory research (Hair et al., 2005). We use both the shorter scale (ESE*) and the original scale (ESE) to enable comparisons with earlier studies.

Insert Table 1 about here

Finally, in order to measure general talent (in contrast to entrepreneurial talent), we use the ten-item general self-efficacy (GSE) scale from Schwarzer and Jerusalem (1995). Table 1 provides a list of all items. For these items, a common factor analysis shows a single factor with an eigenvalue above one. Cronbach's alpha of 0.75 indicates a sufficient internal reliability.

\subsection{Procedures}

Six experimental sessions with 111 participants were conducted in December 2007 at the experimental laboratory ELSE at Utrecht University in the Netherlands. The experiment sessions were computerized, using z-tree (Fischbacher, 2007). Participants were randomly seated at PCs, separated from each other by visual screens. Instructions were then distributed and questions were answered in private. ${ }^{7}$ At the beginning of the experiment, participants were randomly assigned to be investors or non-investors (labeled as Group A and Group B, respectively) and were privately informed about their group on one of the entry screens. Additionally, on each

\footnotetext{
${ }^{6}$ After adding additional items, Weitzel et al. (2010) find that the ESE items form two dimensions, where business talent is separate from the item related to creativity. In our data, the two dimensions correlate significantly ( $r=0.23$ with $p=0.03$ ), but this is only due to five data points that score extremely low on creativity (correlation without these data points is $r=0.11$ with $p=0.35$ ). Our exploitation of the potential multi-dimensionality is limited, because our analysis builds on fewer items than Weitzel et al. (2010). In order to enable comparisons between studies, we decided to report results not only for the reduced scale with sufficient internal reliability, but also for the full scale. Furthermore, excluding the creativity item from the full scale, which represents what Weitzel et al. (2010) call 'business talent', reveals qualitatively the same results as the full scale (detailed analyses available on request from the first author).

7 Upon request, the instructions are available from the corresponding author.
} 
of the 36 decision screens, there was a reminder of their group assignment. Participants stayed in their group throughout the whole session. At the end of the sessions, participants were asked to fill in a questionnaire. During this time, payoffs were prepared by the instructor. In all six sessions, the group of non-investors (Group B) consisted of four participants. There were between 13 and 16 investors per session in Group A, with an average of 14.5 investors.

The sequence of the 36 decisions screens was randomly determined for each participant individually. The initial endowments of participants in group A and B were announced as part of the instructions. The outcomes of the coin tosses were revealed at the very end of the session. To keep non-investors busy, we asked them to go through the same set of 36 investment decision screens as Group A. Group B, however, was informed that their decisions are purely hypothetical and that their own payoffs are solely determined by investors. As non-investors' decisions are not incentive compatible, we do not include them in our analysis. All results reported in this paper refer to the group of investors only.

Earnings of investors were determined by the average payoff of four individually and randomly selected scenarios. To keep the variation of payoffs manageable and also to stress that all investment multiples are equally important we randomly selected one decision per multiple. Earnings of non-investors were determined by only one randomly and separately selected scenario. For example, if the scenario with a multiple of 2 and an impact factor of +0.5 was randomly selected, all respective investment decisions and winnings of investors, irrespective of their position in the individual decision sequences, were used to calculate non-investors' payoffs. Selecting only one out of the 36 scenarios prevented potential strategizing by investors on averaging effects across several positive and negative externalities. Further, it ensured the maximum variance of externalities on non-investors' payoffs.

Before starting the experiment, investors were informed that they receive a fixed budget of 8 Euros for each of their 36 investment decisions. Note that not all of these budgets were finally paid out, but only the average of four randomly selected scenarios. Participants in Group B were informed that they receive an initial budget of $B^{N}=14$ Euros in order to avoid bankruptcy. This amount is equal to the expected 
payoff of an investor. ${ }^{8}$ In the worst case, this would leave non-investors with a showup fee of 2 Euro. ${ }^{9}$ The average payoff was 11.31 Euro for investors and 14.85 Euro for non-investors, with a standard deviation of 5.98 Euro and 2.58 Euro, respectively.

\section{Results}

For the 87 participants who have been assigned the role as investors, we find substantial correlation between entrepreneurial self-efficacy and general self-efficacy ( $\mathrm{r}_{\mathrm{ESE}, \mathrm{GSE}}=0.41$ with $p<0.001, \mathrm{r}_{\mathrm{ESE}}^{*}, \mathrm{GSE}=0.44$ with $\left.p<0.001\right)$. Entrepreneurial intent correlates moderately with general self-efficacy $(r=0.263$ with $p=0.01)$ and weakly with entrepreneurial self-efficacy $\left(\mathrm{r}_{\mathrm{EI}, \mathrm{ESE}}=0.15\right.$ with $p=0.16, \mathrm{r}_{\mathrm{EI}, \mathrm{ESE}} * 0.23$ with $p=$ $0.03)$. Note that intent positively correlates with being a foreign student ( $r=0.44$ with $p<0.001$ ), and that study duration negatively correlates with general self-efficacy ( $r=$ -0.22 with $p<0.04)$. For more details, we refer to Table 2 .

Insert Table 2 about here

Figure 1 plots the average responses across all treatments. As expected, we observe that the larger the potential gain (i.e., the larger the multiple), the more people invest. With regard to the impact factor, the figure suggests that this treatment variable primarily matters when it changes its sign from a negative externality to a nonnegative externality and vice versa. The actual magnitude of the impact variable, however, does not seem to have a significant effect on the investment level. Below, this will also be shown econometrically. Further, when there is no externality participants seem to invest as much as in the presence of a positive externality.

Insert Figure 1 about here

\footnotetext{
${ }^{8}$ A risk-averse participant in Group A would not invest in coin tosses with multiples $m=1.75$ or $m=2$, but fully invest if $m=4$ or $m=6$. This would result in an expected payoff of $\left(8+8+0.5 * 4 * 8+0.5 *^{*} 6 * 8\right) / 4=$ 14.

${ }^{9}$ Assume a multiple $m=6$ and that all participants in Group A invest their fixed budget and win. Given a budget of 8 Euro and an impact factor of $\alpha=\mathbf{- 1}$, the four participants in Group B would have to equally share a negative externality of 48 Euro, leaving each of them with 14-12 = 2 Euro.
} 
To explore the data more systematically, we employ regression analyses. The data from our experiment are clustered at the subject and the session level, because of multiple responses by the same individual and the pooling of externalities at the session level. In order to handle this data structure, we employ a multilevel modeling approach by using a random coefficient regression (Cohen et al., 2003) based on procedures suggested by Rabe-Hesketh and Skondal (2005) for the software package STATA. At the level of the session, we estimate a random intercept. We estimate random coefficients for the period of the decision, the type of the decision (i.e., destructive, neutral, or productive), and the multiple at the level of single individuals. Table 3 reports the regression results. We also run the analyses with simpler model structures - i.e., only with random intercepts - or only with a single level of clustering withinsubject (available from the corresponding author upon request). In both cases, our results remain intact.

Insert Table 3 about here

The first row in Table 3 (Model I) includes control variables as well as the period and dummies for multiples. The period does not play a significant role, but the multiples clearly do: compared to a potential doubling of the investment - i.e., $m=2$ participants invest - as could be expected - significantly less for $m=1.75\left(\beta_{x 175}=-.69\right.$, $z=5.74$ and $p<0.001)$, and significantly more for $m=4.00\left(\beta_{x 400}=1.65, z=8.64\right.$ and $p$ $<0.001)$ and for $m=6.00\left(\beta_{x 600}=2.43, z=11.40\right.$ and $\left.p<0.001\right)$.

Model II additionally includes a contrast code $D v P$ for destructive versus productive as well as a dummy $N$ for neutral scenarios. The contrast code enables us to directly test the difference between destructive and productive scenarios, which is our main interest in this study. Consistent with widespread empirical evidence that people care about others (e.g., Fehr \& Schmidt, 1999; Bolton \& Ockenfels, 2000; Andreoni \& Miller, 2002), we find that participants invest much more in scenarios with positive than with negative externalities $\left(\beta_{D v P}=0.37, z=3.83\right.$ and $\left.p<0.001\right)$. The dummy for neutral settings captures an effect of the presence of externalities independent of their sign. Participants decide differently depending of whether or not there are externalities, may they be positive or negative. Social considerations might, for 
instance, reduce the attention given to risk considerations. We observe that in the neutral scenario, participants invest more compared to the average of scenarios with externalities $\left(\beta_{N}=0.41, z=3.11\right.$ and $\left.p=0.002\right)$. This effect is driven by destructive settings. For productive scenarios, the investment is not significantly different from its level in neutral settings $\left(\beta_{N}-\beta_{D v P}=0.04, z=0.37\right.$ and $\left.p=0.71\right)$.

Model III reports the regression results for entrepreneurial intent. We find no main effect $\left(\beta_{E I}=-0.17, z=1.06\right.$ and $\left.p=0.29\right)$, but significant interactions. Panel $\mathrm{A}$ in Figure 2 visualizes the interaction effects. There is a significant difference between the destructive and the productive setting with respect to the relation between intent and investments $\left(\beta_{E I x D v P}=0.19, z=2.12\right.$ and $\left.p=0.03\right)$. As shown in Figure 2 , the overall effect (main plus interaction effect) indicates no difference in investment behavior with regard to neutral opportunities $\left(\beta_{E I}+\beta_{E I X N}=0.05, z=0.32\right.$ and $\left.p=0.75\right)$ or productive opportunities $\left(\beta_{E I}+\beta_{E I x D v P}=0.02, z=0.11\right.$ and $\left.p=0.92\right)$, but a significantly lower investment in the face of destructive opportunities $\left(\beta_{E I}-\beta_{E I x D v P}=-0.36, z=1.96\right.$ and $p=0.05$ ). The more participants consider a start-up as a likely future occupational option, the less they seem to be willing to accept damage associated with their own gains, although they invest at equally high levels as others in non-destructive scenarios. This result for entrepreneurial intent stands in contrast to the findings for entrepreneurial talent. Weitzel et al. (2010) find that people with entrepreneurial talent care less about others. In order to enable a comparison, it is therefore important to estimate Weitzel et al.'s (2010) previously found effect of entrepreneurial talent with our data.

Insert Figure 2 about here

Models IV and V report the regression results for entrepreneurial self-efficacy using the measurement without and with a weak item, respectively (ESE*, ESE). For both models, we find a significant main effect $\left(\beta_{E S E^{*}}=0.40, z=2.72\right.$ and $p=0.006$ and $\beta_{E S E}=0.38, z=2.54$ and $p=0.01$ ). We find no interaction effects. Indeed, the visualizations in Panels B and C of Figure 2 indicate no interaction effect. Those who believe to be entrepreneurially talented invest more across all scenarios and the difference in destructive scenarios is about as large as in productive scenarios 
$\left(\beta_{E S E^{*}{ }_{X V v} P}=0.01, z=0.07\right.$ and $\left.p=0.95\right)$. Hence, participants with entrepreneurial talent invest more in destructive scenarios, which is consistent with Weitzel et al. (2010).

For general self-efficacy (Model VI and Panel D in Figure 2), we do not find any statistically significant effect. Neither the main effect ( $\beta_{G S E}=.03, z=0.22$ and $p=0.82$ ) nor the interaction effects are significant $\left(\beta_{G S E X N}=-.01, z=.11\right.$ and $p=0.91, \beta_{G S E x D v P}=-$ $.03, z=.28$ and $p=0.78$ ).

As a robustness check, Model VI is re-estimated including all three variables: entrepreneurial intent, entrepreneurial self-efficacy, and general self-efficacy. The results remain robust. The results of Models II - V suggest that the effects of intent differ from entrepreneurial self-efficacy, and these in turn differ from general selfefficacy. The full Model VI enables us to statistically test for possible differences between the three variables. Note that these variables were standardized before being entered into the regression such that their effect sizes are comparable. We find that the three coefficients for the main effect and the two interaction effects of entrepreneurial intent jointly and significantly differ from entrepreneurial self-efficacy $\left(\chi^{2}(6)=19.61\right.$ with $\left.\mathrm{p}=0.003\right)$. This also applies when testing the interaction with destructive versus productive scenarios individually, albeit at the $10 \%$ level $\left(\chi^{2}(6)=\right.$ 5.59 with $p=0.06$ ). Similarly, the three coefficients of entrepreneurial self-efficacy significantly differ from general self-efficacy effects $\left(\chi^{2}(6)=13.31\right.$ with $\left.p=0.04\right)$.

In further robustness checks, we tested the need for modeling the session level and the use of random coefficients at the subject level. We removed corresponding parameters from the model and used Likelihood-ratio tests to check whether the model fit decreases. This is a rather conservative test (Self \& Liang, 1994). The results for the models that are of special interest (Models III and IV) suggest that controls for session and subject level effects are indeed needed. When removing the session level random effects, the fit of the estimations significantly decreases for Model III and the change just marginally misses significance for Model IV $\left(\chi^{2}(1)=5.67\right.$ with $p=0.02$ and $\chi^{2}(27)=3.70$ with $\left.p=0.05\right)$. When dropping the random coefficients at the individual level, the models' fit significantly drops $\left(\chi^{2}(27)=1543.47\right.$ with $p<0.001$ and $\chi^{2}(27)=$ 1506.28 with $p<0.001)$. Independent of the specification, however, the estimated 
effects associated with destructive versus productive settings are consistent with those reported in Table 3.

To further illustrate the robustness of our results non-parametrically, we split the sample, for each externality category (destructive, neutral, productive), along the medians of the self-efficacy and intent variables. Figure 3 plots the average investments within these sub-samples. In support of the robustness of our findings, all significant effects in the structural regression analysis are also visible in the interaction plots based on simple sample-splits.

Insert Figure 4 about here

\section{Discussion}

This paper advances the research on personality characteristics that correlate with entrepreneurs (compare Rauch \& Frese, 2007; Hmieleski \& Baron, 2009; Zhao et al., 2010; Gruber, in press) by focusing on benevolent behavior. In doing so, we inform economic models of entrepreneurship that make assumptions about the otherregarding preferences of potential and actual entrepreneurs (e.g., Baumol, 1990; Casmatta 2003; Eltizur \& Gavious, 2003; Fairchild, 2010; Fairchild, in press). We believe that benevolent preferences not only have a situational component (Houser and Xiao, 2010), but also include a trait-like element so that people who have the tendency to care about others also show this behavior in different contexts. In fact, Weitzel et al. (2010) find that, despite varying absolute levels of benevolent behavior across different versions of the dictator game, the correlation of this behavior with entrepreneurial self-efficacy is rather stable. Extending this research, we test in a laboratory environment whether benevolent behavior in an investment decision is correlated with entrepreneurial intentions. Furthermore, we compare the correlations of entrepreneurial intent and entrepreneurial self-efficacy, because prior research indicates that there is no perfect mapping between the two.

We find that our participants generally invest less in destructive than in

productive opportunities. This is in line with previous results on other-regarding preferences, which show that, on average, people care about others (e.g., Fehr \& Schmidt, 1999; Bolton \& Ockenfels, 2000). Our experimental treatments include 
substantial risks and the element of benevolence is less salient than in, for example, dictator games (Oechssler, 2009). Despite this arguable more realistic setting for entrepreneurial decisions, we find that benevolent considerations still matter and are not crowded out by risk considerations, as suggested by Güth et al. (2008) or Brennan et al. (2008). However, the results also show that benevolent preferences only matter in terms of the binary condition whether or not the investment decisions causes negative (or non-negative) externalities. Participants do not seem to experience a 'warm glow' (Andreoni \& Miller, 2002) from investments with positive externalities when compared with investments with no externalities, nor do they seem to care about the magnitude of positive externalities.

In our introductory, theoretical discussion we have highlighted that both a negative and a positive association of entrepreneurship with benevolence can be established; based on person-organization fit theory (e.g., Schneider, 1987; Zhao et al. 2010), on the entrepreneurs' socialization and roles literature (Starr \& Fondas, 1992), and on fairness perceptions with respect to compensation schemes (Fehr \& Schmidt, 2000; Lazear \& Shaw, 2007). It requires empirical studies to inform research for the further development of such models. We find that participants with high entrepreneurial intent invest as much as others in productive scenarios, but significantly less in destructive settings. This suggests that social considerations do play a supporting role in the decision to start a business. Based on our data, we can only speculate why this might be the case. We tentatively suggest that entrepreneurship as an occupation is characterized by a compensation scheme that is perceived as fairer than many employment relations.

While our results suggest an optimistic view on potential entrepreneurs, i.e. those who actually intent to start a business, our results on entrepreneurial talent (self-efficacy) confirm the more pessimistic predictions of Baumol (1990), which are also supported by Weitzel et al. (2010). Participants who score high on entrepreneurial self-efficacy invest significantly more than others in destructive scenarios. We also find, however, that they invest more in productive scenarios. Hence, in productive scenarios they produce more positive externalities and in the destructive scenarios they also produce more negative externalities. The relative difference between the investments in productive and in destructive opportunities is 
equally large for the more and the less entrepreneurially talented. In our experiment, this suggests that the generally higher investments of participants with more entrepreneurial talent may be due to a generally higher level of risk-taking.

Taken together, our contrasting findings on entrepreneurial talent and intent raise an interesting question: if those who tend to start a business are less likely to exploit destructive opportunities, what career path is then pursued by the entrepreneurially more talented but less benevolent participants? Instead of being confronted with selfish entrepreneurs, we might have to focus more on selfishness in other occupations, such as in managerial careers exploiting business talent. Our results suggest that policies that regulate managerial actions and talent are at least equally important as institutions and incentive systems that try to support productive and avoid destructive entrepreneurship as suggested by Baumol (1990). Our findings also inform research on financial contracting and related moral hazard problems (Fairchild, in press). The problems seem to be smaller for those who want to start their own business compared to other people (e.g., employed managers). If this is supported in more comprehensive studies in the future, venture capitalists and other investors might benefit from applying different contracts to entrepreneurs and ownermanagers vis-à-vis employed managers (compare Fairchild, 2010).

Our results provide no indication that the effects found for participants with entrepreneurial talent also apply to the more generally talented. Hence, in contrast to models of general talent (e.g., Murphy et al., 1991, 1993; Acemoglu, 1995; Mehlum et al., 2003), but consistent with Baumol (1990) and Weitzel et al. (2010), our findings provide additional support for the need to distinguish between entrepreneurial and general talent.

Of course, this study is not without limitations. First, and as discussed in the methodology section and above in this section, we acknowledge the general limitations of the methods used. This particularly applies to the use of self-reports (for a discussion of the appropriateness of the measurement applied in this study, compare Kolvereid \& Isaksen, 2006) and the limited external validity of laboratory experiments and of students as experimental subjects (Schade, 2005; Bello et al., 2009; Schade \& Burmeister, 2009). Second, because entrepreneurial self-efficacy is assumed to influence entrepreneurial intent (Krueger et al., 2000) and general self-efficacy is 
related to work-related self-efficacy (Chen et al. 2004), which entrepreneurial selfefficacy is a part of, the comparison of effects in Model VII, which jointly includes both variables, might suffer from multicollinearity problems. Depending on how shared variance is attributed, the coefficients may vary. Therefore, we also provide the Models III and IV that include these variables separately. Third, our study is limited by the cultural background of our participants. As we have emphasized, the link between entrepreneurial self-efficacy and entrepreneurial intentions is affected by social norms. As such, differences in correlations with other variables might reflect differences in social norms and, more generally, cultural differences. Whether our results from The Netherlands generalize to other contexts, countries and cultures, requires further empirical studies. In fact, it might be useful to explicitly incorporate measures of the institutional and social environment to analyze their effect on participants' behavior.

\section{Conclusion}

Extending research on personality characteristics of entrepreneurs (Rauch \& Frese, 2007; Hmieleski \& Baron, 2009; Zhao et al., 2010; Gruber, in press), we study the correlation of selfishness with entrepreneurial intentions. This mirrors the recent development in personality research, where the five most important traits - openness, conscientiousness, extraversion, agreeableness, and neuroticism - are complemented with a sixth trait - i.e. honesty and humility, which also includes fairness (Ashton \& Lee, 2007). Our observation that entrepreneurial self-efficacy and intent make a difference with respect to selfish behavior, but general talent does not, illustrates that the entrepreneurial personality profile plays a distinctive role in our society.

Finding that entrepreneurial intent is associated with smaller investments in destructive opportunities informs research on models of entrepreneurship, such as those on moral hazard in contractual relationships between entrepreneurs and venture capitalists (Fairchild, 2010). Furthermore, the observation that entrepreneurial self-efficacy is associated with a higher willingness to accept negative externalities, while entrepreneurial intent is associated with a lower willingness to harm others, raises the question about the allocation of selfish entrepreneurial talent. Models of allocations of entrepreneurial talent need to take this difference into 
account (compare Baumol, 1990; Murphy et al., 1993; Acemoglu, 1995). Our research tentatively suggests that more selfish and entrepreneurially talented people might not allocate into formal entrepreneurship, but find other occupations in which they can exploit their talent more profitably. This study, however, can only speculate about the origins of this effect. Further research is needed to better understand the reasons for this divergence.

Generally, our results call for more research in economics, psychology and entrepreneurship that complements talent allocation models with empirical insights and theoretical models on the allocation of benevolent preferences. In particular for entrepreneurship scholars, the findings of this study (and of Weitzel et al., 2010) suggest that selfishness deserves attention as one of entrepreneurs' distinctive personality characteristics. More research on this topic could help policy-makers to improve the design of institutions and incentive systems that support productive and avoid destructive behavior in entrepreneurship -- but also, and maybe even more so, in wage- and bonus-earning occupations. Finally, it could also inform and help theorists studying moral hazard problems in entrepreneurs' relations to their business partners. 


\section{References}

Acemoglu, D. (1995). Reward structures and the allocation of talent. European Economic Review, 39, 17-33.

Ajzen, I. (1991). The theory of planned behavior. Organizational Behavior and Human Decision Processes, 50, 179-211.

Alevy, J. E., Haigh, M. S., \& List, J. A. (2007). Information cascades: Evidence from a field experiment with financial market professionals. Journal of Finance, 62(1), 151-180.

Andreoni, J., \& Miller, J. (2002). Giving according to GARP: An experimental test of the consistency of preferences for altruism. Econometrica, 70, 737-753.

Ashton, M. C., \& Lee, K. (2007). Empirical, theoretical, and practical advantages of the HEXACO model of personality structure. Personality and Social Psychology Review, 11, 150-166.

Baumol, W. (1990). Entrepreneurship: Productive, inproductive and destructive. Journal of Political Economy, 98, 893-921.

Bello, D., Leung, K., Radebaugh, L., Tung, R. L., \& van Witteloostuijn, A. (2009). From the editors: Student samples in international business research. Journal of International Business Studies, 40, 1-5.

Bimore, K., \& Shaked, A. (2010). Experimental economics: Where next? Journal of Economic Behavior \& Organization, 73, 87-100.

Bird, B. J. (1988). Implementing entrepreneurial ideas: The case for intention. Academy of Management Review, 13, 442-453.

Bolton, G., \& Ockenfels, A. (2000). ERC: A theory of equity, reciprocity and competition. American Economic Review, 90, 166-193.

Bonnett, C., \& Furnham, A. (1991). Who wants to be an entrepreneur? A study of adolescents interested in a young enterprise scheme. Journal of Economic Psychology, 12, 465-478.

Bowen, H. P., \& De Clercq, D. (2008). Institutional context and the allocation of entrepreneurial effort. Journal of International Business Studies, 39, 747767.

Brennan, G., Güth, W., Gonzalez, L., \& Levati, M. V. (2008) Attitudes toward private and collective risks in individual and strategic choice situations. Journal of Economic Behavior \& Organization, 67, 253-262.

Brockhaus, S. R. H. (1980). Risk taking propensity of entrepreneurs. Academy of Management Journal, 23, 509-520.

Brockhaus, R. (1982) The psychology of the entrepreneur. In: C. Kent, D. Sexton, K. Vesper (Eds) Encyclopedia of Entrepreneurship. pp 39-57. Prentice-Hall..

Caliendo, M., Fossen, F., \& Kritikos, A. S. (2009). Risk attitudes of nascent entrepreneurs: New evidence from an experimentally-validated survey. Small Business Economics, 32, 153-167. 
Caliendo, M., Fossen, F., \& Kritikos, A. (2010). The impact of risk attitudes on entrepreneurial survival. Journal of Economic Behavior \& Organization, 76, 45-63.

Casamatta, C. (2003). Financing and advising: Optimal financial contracts with venture capitalists, Journal of Finance, 58(5), 2059-2085.

Chen, C. C., Greene, P. G., \& Crick, A. (1998). Does entrepreneurial self-efficacy distinguish entrepreneurs from managers. Journal of Business Venturing, 13(4), 295-316.

Chen, G., Goddard, T. G., \& Casper, W. J. (2004). Examination of the relationships among general and work-specific self-evaluations, work-related control beliefs, and job attitudes. Applied Psychology: An International Review, 53 (3), 349-370.

Cohen, J., Cohen, P., West, S. G., \&Aiken, L. S. (2003). Applied Multiple Regression/Correlation Analysis for the Behavioral Sciences. Third edition. Mahwah, NJ, London: Lawrence Erlbaum Associates, Publishers.

Dees, G. (2007). Taking social entrepreneurship seriously. Society, 44(3), 24-31.

Drehmann, M., Oechssler, J., \& Roider, A. (2005). Herding and Contrarian Behavior in Financial Markets-An Internet Experiment. American Economic Review, 95, 1403-1426.

Elitzur, R., \& Gavious, A. (2003). Contracting, signalling, and moral hazard: a model of entrepreneurs, 'angels,' and venture capitalists. Journal of Business Venturing, $18,709-725$.

Elston, J. A., \& Audretsch, D. B. (forthcoming). Financing the Entrepreneurial Decision: An Empirical Approach Using Experimental Data on Risk. Small Business Economics.

Fairchild, R. (2010). Fairness Norms and Self-interest in Venture Capital/Entrepreneur Contracting and Performance. Mimeo. School of Management, University of Bath.

Fairchild, R. (in press). An entrepreneur's choice of venture capitalist or angelfinancing: A behavioral game-theoretic approach. Journal of Business Venturing.

Fehr, E. , \& Schmidt, K. M. (1999). Theory of Fairness, Competition and Cooperation. Quarterly Journal of Economics, CXIV (3), 817-868.

Fehr, E., \& Schmidt, K. M. (2000). Fairness in Strategic Interactions. Fairness, incentives, and contractual choices. European Economic Review, 44, 10571068.

Fehr, E., \& Schmidt, K. M. (2010). On nequity version: A eply to Binmore and Shaked. Journal of Economic Behavior \& Organization, 73, 101-108.

Fischbacher, U. (2007). z-Tree: Zurich Toolbox for Ready-Made Economic Experiments. Experimental Economics, 10(2), 171-178.

Gruber, M., (in press). Exploring the origins of organizational paths: Empirical evidence from newly founded firms. Journal of Management. 
Güth, W., Levati, V., \& Ploner, M. (2008). On the Social Dimension of Time and Risk Preferences: An Experimental Study. Economic Inquiry, 46(2), 261-272.

Hair, J.F., Black, W.C., Babib, B.J., Anderson, R.E., \&Tatham, R.L. (2005). Multivariate Data Analysis. New Jersey: Pearson, Prentice Hall.

Hilbig, B. E., \& Zettler, I. (2009).. Pillars of cooperation: Honesty-Humility, social value orientations, and economic behavior. Journal of Research in Personality, 43, 516-519.

Hmieleski, K. M., \& Baron, R. A. (2009). Entrepreneurs' optimism and new venture performance: A social cognitive perspective. Academy of Management Journal, 52(3), 473-488.

Houser, D., \& Xiao, E. (2010). Understanding context effects. Journal of Economic Behavior \& Organization, 73(1), 58-61.

Ikovleva, T., \& Kolvereid, L. (2009). An integrated model of entrepreneurial intentions. International Journal of Business and Globalisation, 3, 66-80.

John, O. P., \& Srivastava, S. (1999). The big-five trait taxonomy: History, measurement, and theoretical perspectives. In: L. A. Pervin, \& O. P. John (Eds), Handbook of personality: Theory and Research (2nd ed.). pp 102-139, New York: Guilford Press.

Judge, T. A., Locke, E. A., \& Durham, C. C. (1997). The dispositional causes of job satisfaction: A core evaluations approach. Research in Organizational Behavior, 19, 151-188.

Kirzner, I. (1973). Competition and Entrepreneurship. Chicago: University of Chicago Press.

Kirzner (1997) Entrepreneurisal Discovery and the Competitive Market Process: An Austrian Approach. Journal of Economic Literature 35: 60-85.

Kolvereid, L., \& Isaksen, E. (2006). New business start-up and subsequent entry into self-employment. Journal of Business Venturing, 21, 866-885.

Krueger, N. (2009). Entrepreneurial Intentions Are Dead: Long Live Entrepreneurial Intentions. In: A. L. Carsrud, M. Brännback (Eds) Understanding the Entrepreneurial Mind. International Studies in Entrepreneurship, 24, 51-72.

Krueger, N. F., Reilly, M. D., \& Carsrud, A. L. (2000). Competing Models of Entrepreneurial Intentions. Journal of Business Venturing, 15, 411-432.

Lazear, E. P., \& Shaw, K. L. (2007). Personnel Economics: The Economist's View of Human Resources. Journal of Economic Perspectives, 21(4). 91-114.

Locke, E., \& Baum, R. (2007). Entrepreneurial motivation. In J. Baum, M. Frese and R. Baron (Eds.), The Psychology of Entrepreneurship. pp. 41-65. Mahwah, NJ: Erlbaum.

Mehlum, H., Moene, K., \& Torvik, R. (2003). Predator or prey? Parasitic enterprises in economic development. European Economic Review, 47, 275-294. 
Murphy, K., Shleifer, A., \& Vishny, R. (1991). The allocation of talent: Implications for growth. Quarterly Journal of Economics, 106, 503-530.

Murphy, K., Shleifer, A., \& Vishny, R. (1993). Why is rent-seeking so costly to growth? American Economic Review, 83, 409-414.

Oechssler, J. (2010). Searching beyond the lamppost: Let's focus on economically relevant questions. Journal of Economic Behavior \& Organization, 73, 65-67.

Rabe-Hesketh, S., \& Skrondal, A. (2005). Multilevel and Longitudinal Modeling Using Stata. College Station, TX: Stata Press.

Rauch, A., \& Frese, M. (2007). Born to be an entrepreneur? Revisiting the personality approach to entrepreneurship. In: J.R. Baum, M. Frese, R. Baron (Eds). The Psychology of Entrepreneurship Research. pp 41-65. Lawrence Erlbaum Associates, Mahwah, NJ.

Rotter, J. B. (1975). Some problems and misconceptions related to the construct of internal versus external control of reinforcement. Journal of Consulting and Clinical Psychology, 43(1), 56-67.

Schade, C. (2005). Dynamics, experimental economics, and entrepreneurship. Journal of Technology Transfer, 30(4), 409-431.

Schade, C., \& Burmeister, K. (2009). Experiments on entrepreneurial decision making: A different lens through which to look at entrepreneurship. Foundations and Trends in Entrepreneurship, 5(2), 81-134.

Schneider, B. (1987). The people make the place. Personnel Psychology ,40. 437-453.

Schumpeter, J. A. (1934). The Theory of Economic Development. Cambridge MA: Harvard University Press.

Schwarzer, R., \& Jerusalem, M. (1995). Generalized self-efficacy scale. In: J. Weinmann, M.Johnston (Eds) Measures in Health Psychology: A User's Portfolio. pp 3537. Windsor, UK: NFER-NELSON.

Self, S. G., \& Liang, K.-Y. (1987). Asymptotic properties of maximum likelihood estimators and likelihood ratio tests under nonstandard conditions. Journal of the American Statistical Association, 82, 605-610.

Shane, S., \& Venkataraman, S. (2000). The Promise of Entrepreneurship as a Field of Research. Academy of Management Review, 25, 217-226.

Shane, S. (2003). A General Theory of Entrepreneurship: The IndividualOpportunity Nexus. Cheltenham, UK: Edward Elgar.

Sobel, R. S. (2008). Testing Baumol: Institutional quality and the productivity of entrepreneurship. Journal of Business Venturing, 23, 641-655.

Starr, J., \& Fondas, N. (1992). A model of entrepreneurial socialization and organization formation. Entrepreneurship Theory and Practice, 17(1), 67-78.

Tracey, P., \& Jarvis, O. (2007). Toward a theory of social venture franchising. Entrepreneurship Theory \& Practice, 31(5), 667-685. 
Weitzel, U., Urbig, D., Desai, S., Sanders, M., \& Acs, Z. (2010). The good, the bad, and the talented: Entrepreneurial talent and selfish behaviour. Journal of Economic Behvaior \& Organization, 76, 64-81.

Wijbenga, F. H., \& van Witteloostuijn, A. (2007). Entrepreneurial locus of control and competitive strategies - The moderating effect of environmental dynamism. Journal of Economic Psychology, 28, 566-589.

Wilson, B. J. (2010). Social preferences aren't references. Journal of Economic Behavior \& Organization, 73, 77-82.

Wilson, F., Kickul, J., \& Marlino, D. (2007). Gender, entrepreneurial self-efficacy, and entrepreneurial career intentions: Implications for entrepreneurship education. Entrepreneurship: Theory \& Practice, 31, 387-406.

Zhao, H., Seibert S. E., \& Hills G. (2005). The mediating role of self-efficacy in the development of entrepreneurial intentions. Journal of Applied Psychology, 90(6), 1265-1272.

Zhao, H., Seibert, S.E., \& Lumpkin, G.T. (2010). The relationship of personality to entrepreneurial intentions and performance: A meta-analytic review. Journal of Management, 36, 381-404. 
FIGURE 1: Average investment for each impact-multiple combination

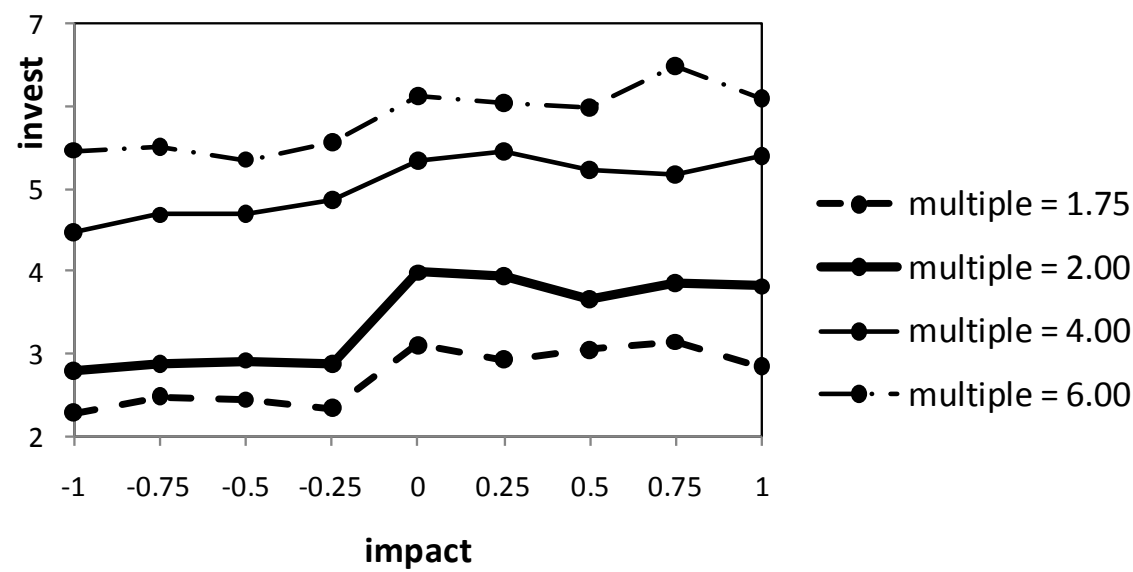

FIGURE 2: Interaction plots based on regressions
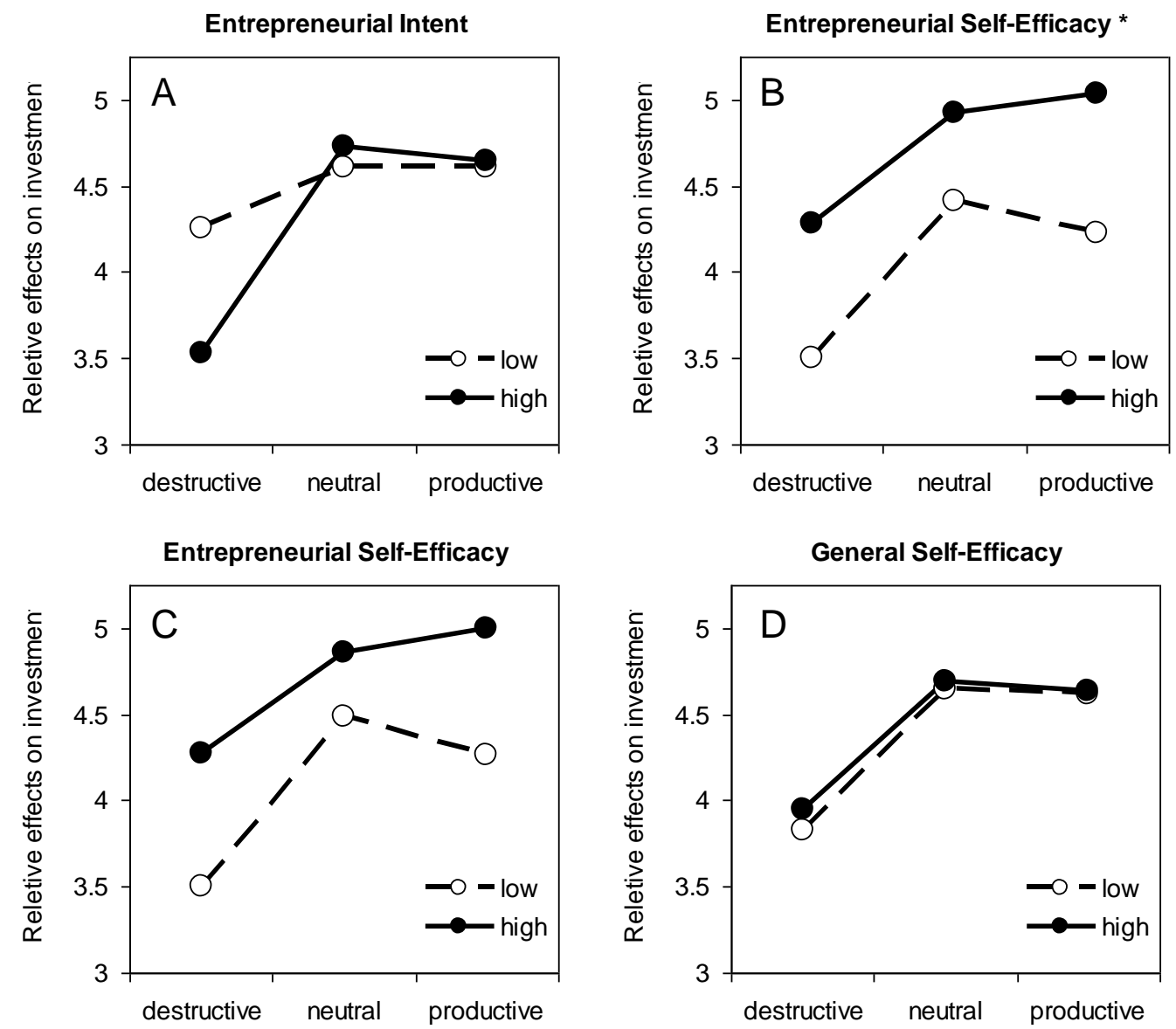

* Excluding one weak item from the original measurement proposed by Wilson et al. (2007) 
FIGURE 3: Interaction plots based on median-based sample splits
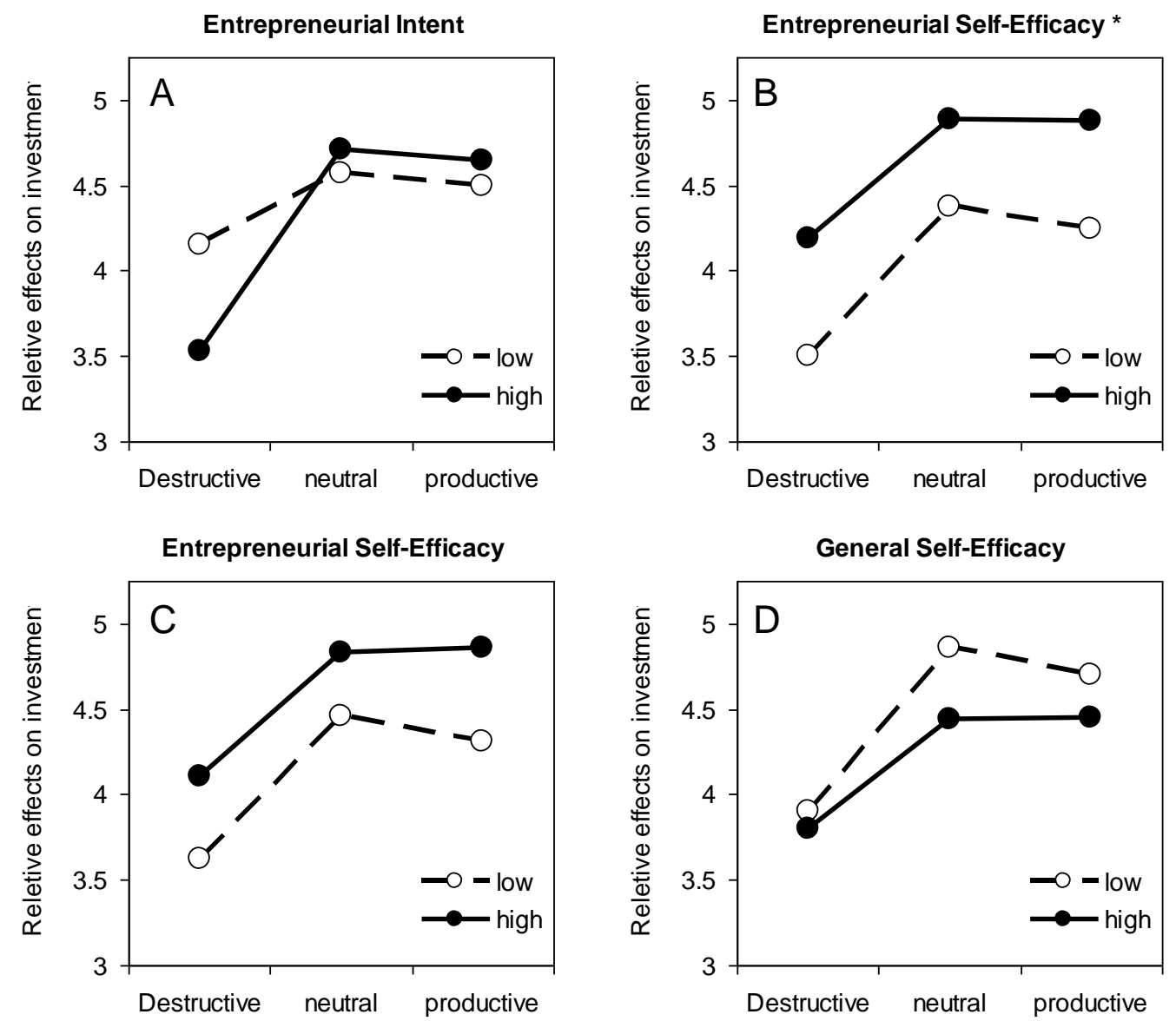

Notes: Samples splits are based on the median. The median is used to generate balanced sub-samples with the following splits: entrepreneurial intent (larger than 11.0 vs. less or equal to 11.0), entrepreneurial self-efficacy ESE (larger than 3.5 vs. less than or equal to 3.5), ESE* (larger than or equal to 3.6 vs. larger than 3.6), general self-efficacy GSE (larger than or equal to 3.1 vs. larger than 3.1).

* Excluding one weak item from the original measurement proposed by Wilson et al. (2007) 


\section{TABLE 1. Overview of the self-efficacy measures used in this study}

\section{Entrepreneurial self-efficacy (Wilson et al., 2007)}

Please answer the following questions on a scale from 1 to 5 , where $1=$ much worse, $2=a$ little worse, $3=$ about the same, $4=$ a little better, $5=$ =much better.

How do you compare yourself to fellow students in your ability to solve problems?
a) ... solve problems?
d) ... get people to agree with you?
b) ... manage money?
e) $\quad . .$. be a leader?
c) $\quad$... be creative?
f) .... make decisions?

General self-efficacy (Schwarzer \& Jerusalem, 1995)

Please state to which extent you think the following statement is true on a scale from 1 to 4 , where $1=$ not at all true, $2=$ barely true, $3=$ somewhat true, $4=$ completely true.

a) I can always manage to solve difficult problems if I try hard enough.

b) If someone opposes me, I can find the means and ways to get what I want.

c) It is easy for me to stick to my aims and accomplish my goals.

d) I am confident that I could deal efficiently with unexpected events.

e) Thanks to my resourcefulness, I know how to handle unforeseen situations.

f) I can solve most problems if I invest the necessary effort.

g) I can remain calm when facing difficulties because I can rely on my coping abilities.

h) When I am confronted with a problem, I can usually find several solutions.

i) If I am in trouble, I can usually think of a solution.

j) I can usually handle whatever comes my way.

\section{TABLE 2: Pearson correlation of the individual-specific characteristics}

\begin{tabular}{llllllllll}
\hline \hline & $\mathbf{1}$ & $\mathbf{2}$ & $\mathbf{3}$ & $\mathbf{4}$ & $\mathbf{5}$ & $\mathbf{6}$ & $\mathbf{7}$ & $\mathbf{8}$ & $\mathbf{9}$ \\
\hline Mean & 21.7 & .63 & .32 & 4.39 & .28 & 19.8 & 3.52 & 3.53 & 3.10 \\
Standard deviation & 3.14 & .49 & .47 & 1.35 & .45 & 25.2 & 0.65 & 0.57 & 0.35 \\
Min & 17 & 0 & 0 & 1 & 0 & 0 & 1.80 & 2.33 & 2 \\
Max & 31 & 1 & 1 & 6 & 1 & 100 & 5 & 5 & 3.9 \\
\hline 1 Age & - & & & & & & & & \\
2 Female & -0.10 & - & & & & & & & \\
3 Foreign & $0.34^{* *}$ & 0.02 & - & & & & & & \\
4 Study duration & -0.11 & 0.01 & $0.26^{*}$ & - & & & & & \\
5 Economics & -0.00 & 0.04 & $0.46^{* * *}$ & $0.32^{* *}$ & - & & & & \\
6 Entr. Intent & $0.18^{+}$ & 0.07 & $0.44^{* * *}$ & 0.10 & 0.11 & - & & \\
7 Entr. Self-efficacy* & 0.01 & -0.02 & 0.10 & $-0.19^{+}$ & 0.13 & $0.23^{*}$ & $(0.66)$ & & \\
8 Entr Self-efficacy & 0.03 & -0.01 & 0.14 & -0.17 & 0.18 & 015 & $0.95^{* * *}$ & $(0.58)$ & \\
9 General Self-efficacy & 0.05 & -.13 & 0.10 & $-.022^{*}$ & 0.02 & $0.26^{*}$ & $0.44^{* * *}$ & $0.41^{* * *}$ & $(0.75)$ \\
\hline \hline
\end{tabular}

$N=87$

For multi-item measurements, Cronbach's alpha is provided on the diagonal in parenthesis. 
TABLE 3: Regression analyses (maximum likelihood estimations)

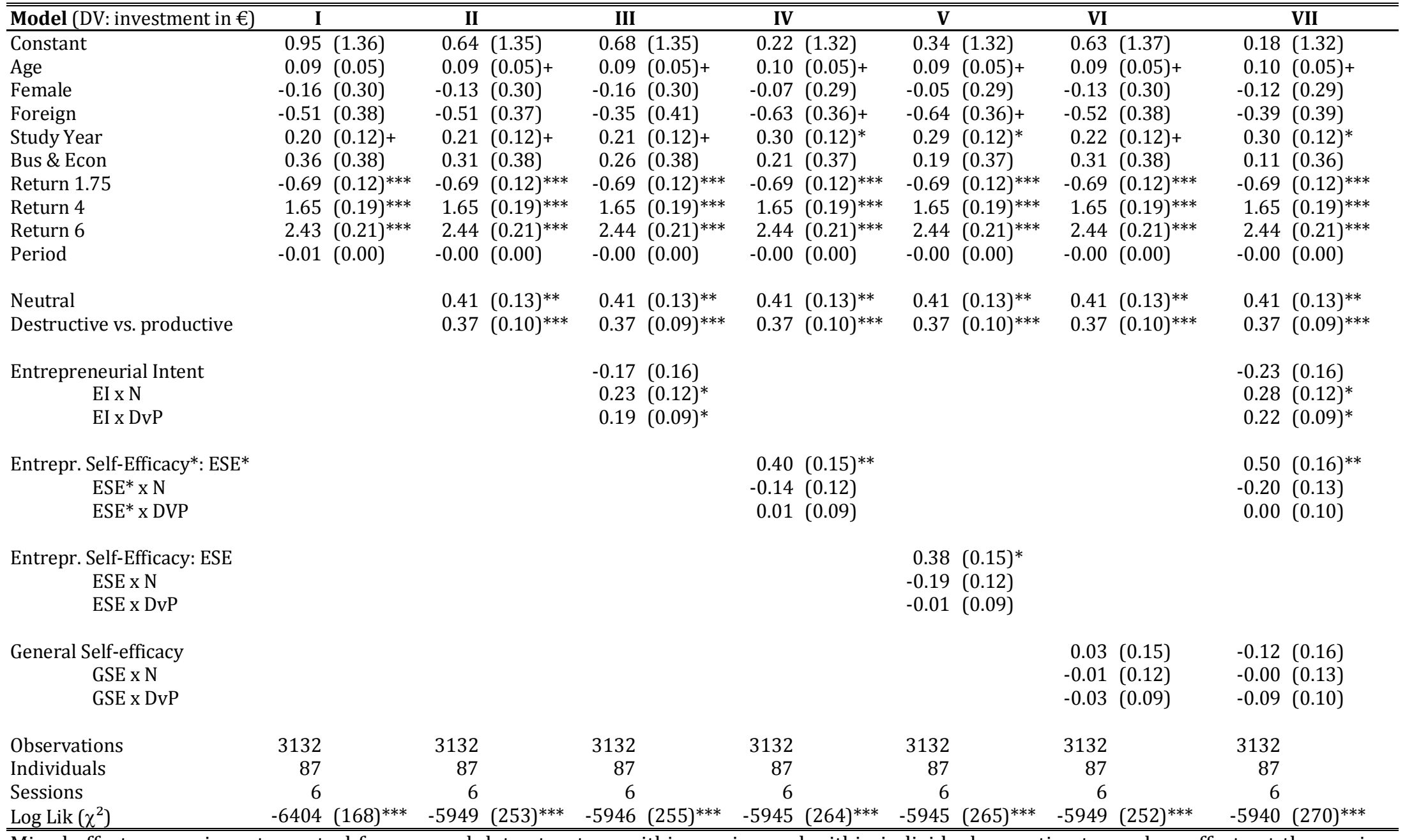

Mixed effect regressions; to control for grouped data structure within session and within individual we estimate random effects at the session level and at the level of individuals we estimate random effects and random coefficients (for all variables varying at the at the level of individual). Standard errors in parentheses. Significance levels: $+\mathrm{p}<0.10,{ }^{*} \mathrm{p}<0.05,{ }^{* *} \mathrm{p}<0.01,{ }^{* * *} \mathrm{p}<0.001$. ESE*: ESE-measurement where one very weak item is excluded from the analysis. 